\title{
Isotopic evidence for temperature variation during the early Cretaceous (late Ryazanian-mid-Hauterivian)
}

\author{
GREGORY D. PRICE ${ }^{1}$, ALASTAIR H. RUFFELL ${ }^{2}$, CHARLES E. JONES ${ }^{3,6}$, ROBERT M. KALIN ${ }^{4}$ \\ \& JÖRG MUTTERLOSE 5 \\ ${ }^{1}$ Department of Geological Sciences, The University of Plymouth, Drake Circus, Plymouth PL4 8AA, UK \\ (e-mail: g.price@plymouth.ac.uk) \\ ${ }^{2}$ School of Geosciences, The Queens University of Belfast, Belfast BT7 1NN, UK \\ ${ }^{3}$ Department of Earth Sciences, University of Oxford, Parks Road, Oxford OX1 3PR, UK \\ ${ }^{4}$ Department of Civil Engineering, The Queen's University of Belfast, Belfast, BT7 1NN, UK \\ ${ }^{5}$ Institut für Geologie, Ruhr-Universität Bochum, Universitätsstr. 150, D-44801, Bochum, Germany \\ ${ }^{6}$ Present address: Department of Geological Sciences, 219 Mitchell Hall, University of Carolina, \\ Chapel Hill NC, USA
}

\begin{abstract}
Oxygen and carbon isotopic compositions have been determined from the belemnite genera Acroteuthis and Hibolites sampled from the early Cretaceous (Ryazanian-Hauterivian) interval of the Speeton Clay Formation, Filey Bay, England. The Speeton Clay Formation consists of a series of claystones and calcareous mudrocks deposited in an epicontinental sea. $\delta^{18} \mathrm{O}$ values from belemnites, which met petrographic and chemical criteria for well preserved skeletal carbonate, indicate warm marine palaeotemperatures $\left(c .12-15^{\circ} \mathrm{C}\right)$ for much of the early Valanginian whilst cool temperatures $\left(<9^{\circ} \mathrm{C}\right)$ are inferred for the earliest Hauterivian. During the remainder of the Hauterivian, temperatures fluctuated considerably and rose to a maximum of $15.5^{\circ} \mathrm{C}$. Changes in kaolinite and smectite abundances, considered to reflect humid and arid phases of climate, correlate with warm and cool episodes. The palaeotemperature record, appears to contradict evidence from cephalopod faunas, which show a Tethyan influx during the inferred early Hauterivian cool period. However, this was a transgressive phase and thus the cephalopods could have been less sensitive to temperature than to water column stability and to land barriers. A positive shift in the carbon isotope profile obtained from the Speeton belemnites appears correlatable with carbon isotope profiles recorded from pelagic Tethyan successions, albeit with somewhat differing absolute values. The data support earlier models of carbon isotope variation, in that positive excursions are associated with an inferred global rise in sea level.
\end{abstract}

Keywords: Yorkshire, early Cretaceous, stable isotopes, palaeoclimate, belemnites.

Many studies focusing upon the early Cretaceous (e.g. Rawson 1973; Hallam et al. 1991; Mitchell 1992; Mutterlose 1992; Ruffell \& Rawson 1994; Williams \& Bralower 1995; Stoll \& Schrag 1996; Ditchfield 1997; Podlaha et al. 1998) have suggested changes of fauna, relative sea level, and humid and arid climatic phases tentatively linked to concurrent temperature change during deposition. For example, a control upon the evolution of largely separate Tethyan and Boreal biotic realms during the early Cretaceous has been considered to be ocean temperature (e.g. Rawson 1973; Stevens 1973). This interpretation has, however, been questioned by Hallam (1984), Doyle (1987) and Mutterlose (1992) who stress that other factors such as the distribution of continents and oceans and salinity were likely to be more important than temperature alone in controlling faunal provinciality. A number of palaeoclimatological studies (e.g. Frakes \& Francis 1988; Stoll \& Schrag 1996; Ditchfield 1997) indicate at least seasonally cold ocean temperatures and the possibility of limited polar ice during the early Cretaceous (but see also Bennett \& Doyle 1996). Likewise, Weissert \& Lini (1991) also proposed early Cretaceous icehouse interludes based upon carbon isotope fluctuations. A precise relationship between $\delta^{13} \mathrm{C}$ excursions, warm climates and sea level change has, however, been the subject of discussion (e.g. Weissert 1989; Lini et al. 1992;
Jenkyns et al. 1994; Chumakov 1995; Gröcke et al. 1999). Recent research by Jenkyns \& Clayton (1997) highlights the possibility of using carbon isotopes derived from wellpreserved belemnites as a potential palaeoceanographic and stratigraphic tool which permits a $\delta^{13} \mathrm{C}$ profile to be directly compared with an oxygen isotope derived palaeotemperature signal.

This study focuses on oxygen and carbon isotope data from belemnites of early Cretaceous (late Ryazanian to mid Hauterivian) age from Speeton, Yorkshire, England, which are compared with existing studies of clay mineralogy and faunal distributions. The detailed lithostratigraphical and biostratigraphical subdivision of the succession permits correlation with other early Cretaceous sections. Palaeotemperature studies using oxygen isotopic ratios from skeletal carbonates are now well established, and the limitations of the procedure have been clearly determined (e.g. Pirrie \& Marshall 1990; Marshall 1992; Ditchfield 1997; Price \& Sellwood 1997). The objectives of this paper are, therefore, firstly to identify which processes were dominant in controlling the oxygen and carbon isotope compositions of the fossil belemnites and secondly to contribute to a better understanding of the climatic and environmental variability affecting deposition of the Speeton Clay Formation during early Cretaceous times. Variation of 


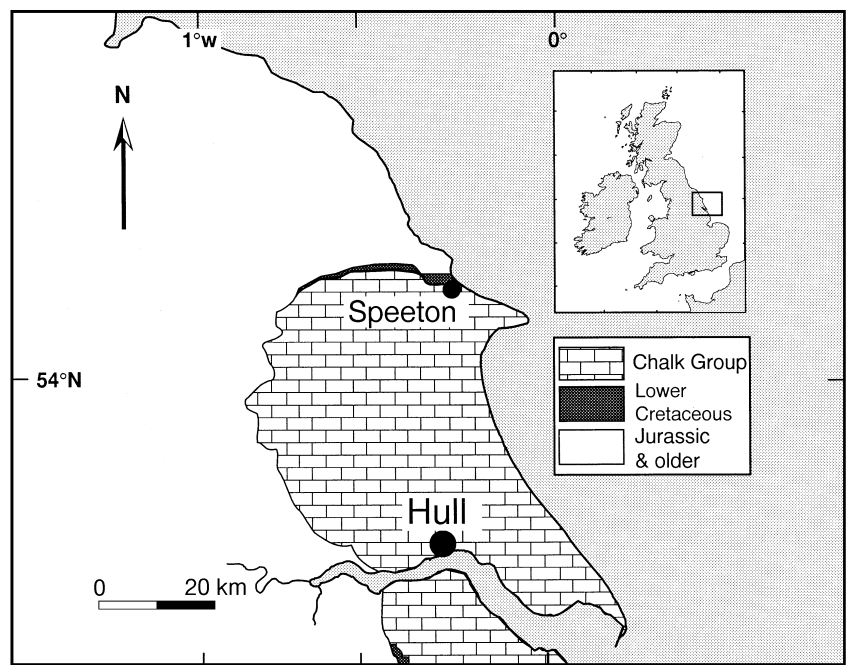

(a)

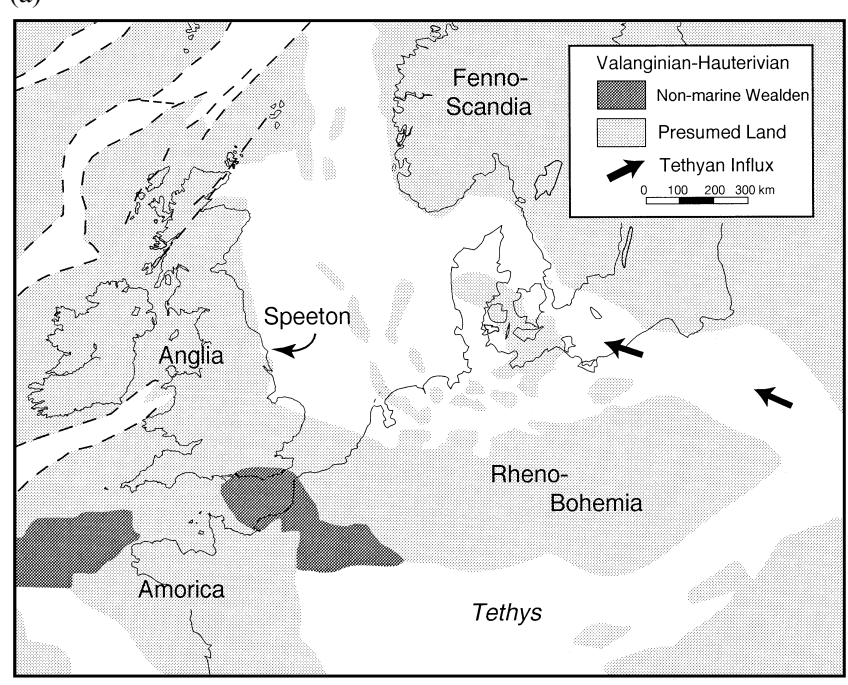

(b)

Fig. 1. Location map of Filey Bay, Speeton, Yorkshire, UK (a) and palaeogeographic setting of Europe during Valanginian-Hauterivian times (b) (after Mutterlose 1997).

the carbon isotope profile derived from the belemnites will be investigated with particular reference to coeval Tethyan $\delta^{13} \mathrm{C}$ profiles which show large fluctuations, thought to be indicative of 'greenhouse' and 'icehouse' intervals (Weissert 1989).

\section{Geological setting and sampling}

The Speeton Clay Formation is exposed at Filey Bay, Speeton, Yorkshire which was located, during the early Cretaceous, on the southern margin of the Southern North Sea at a palaeolatitude of $c .40-45^{\circ} \mathrm{N}$ (see Smith et al. 1994, fig. 1). During the early Cretaceous the northwest European area formed the southernmost extension of the Boreal-Arctic sea with seaways towards the Tethys in the south (Mutterlose 1992). As the northwest European area lies between the Boreal and Tethyan realms (Fig. 1), it was influenced by influxes of nanoflora and fauna from both realms (Mutterlose 1992). The Speeton Clay Formation consists of interbedded marine claystones and calcareous mudrocks which rest unconformably on the Volgian Kimmeridge Clay Formation (Rawson et al. 1978). The stratigraphical succession has a number of gaps, the most notable of which are in the Lower Ryazanian and Upper Valanginian (Fig. 2). These gaps often contain phosphatic pebbles and concentrations of belemnites and flattened ammonites (a remanié fauna, Rawson et al. 1978). The base of the Valanginian is marked by a major transgression, which may correspond to the Haq et al. (1987) $127.5 \mathrm{Ma}$ maximum flooding surface (Ruffell 1991). During the early Hauterivian a series of minor regressive episodes are recognized (Ruffell 1991). Clay mineralogy and geochemical data have previously been obtained from the Speeton Clay Formation (e.g. Ruffell \& Batten 1990; Knox 1991; Hallam et al. 1991). This highly fossiliferous formation includes belemnites, ammonites and bivalves and has been divided up into four major units, beds A-D, by Lamplugh (1889) according to the affinities of the belemnite fauna. The A beds (Aptian-Albian) and $\mathrm{C}$ beds (Lower-Upper Hauterivian) are dominated by characteristically Tethyan belemnites, whilst the B beds (Barremian) and D beds (Upper Ryazanian-lowermost Hauterivian) are dominated by Boreal belemnites (e.g. Rawson 1973; Mutterlose 1992). From this suite of organisms, the belemnite genera Acroteuthis and Hibolites, which respectively show Boreal and Tethyan affinities from the Upper Ryazanian to mid Hauterivian, were sampled for isotopic analysis.

\section{Analytical procedures}

The preservation of the belemnite rostra has been assessed through the application of trace element and stable isotopic analyses, Scanning Electron Microscopy (SEM) and carbonate staining (following the methodology of Dickson 1966). Carbonate powders were drilled from 29 belemnites, avoiding areas where staining indicated ferroan carbonate and pyrite was observed (see below), and were isotopically analysed on a Micromass Prism III Isotope Ratio Mass Spectrometer with a Multiprep Automated Carbonate System (at Queen's University, Belfast) using 30-50 $\mu \mathrm{g}$ of carbonate with $100 \mu \mathrm{l}$ of distilled $100 \% \mathrm{H}_{3} \mathrm{PO}_{4}$ acid. This is a single acid bath system and the reaction temperature is $90^{\circ} \mathrm{C}$. Isotopic results were calibrated against NBS-19 and an in-house Iceland Calcite Spar sample. The $\delta^{18} \mathrm{O}$ and $\delta^{13} \mathrm{C}$ compositions are reported in per mil (\%) notation with respect to the PDB international standard. Reproducibility for both $\delta^{18} \mathrm{O}$ and $\delta^{13} \mathrm{C}$ was generally better than $\pm 0.1 \%$, based upon replicate analyses. Elemental concentrations ( $\mathrm{Mn}$ and Fe) were determined on $20-40 \mathrm{mg}$ subsamples, analysed using a Perkin Elmer 3100 Atomic Absorption Spectrometer. Based upon replicate analysis, analytical precision was estimated to be less than $\pm 10 \%$ of the measured concentration of each element.

An additional 11 isotopic analyses, of belemnite rostra from Speeton, were carried out on a Finnigan MAT 251 mass spectrometer at Ruhr-Universität Bochum. The preservation of these belemnites has been assessed through visual characterization and trace element analysis, carried out on $20-40 \mathrm{mg}$ subsamples using Inductively Coupled Plasma (ICP) spectrometry analysis on a Perkin Elmer 3000 at the University of Plymouth. Eleven complimentary trace element and isotopic measurements made by Jones (1992) and Jones et al. (1994) on belemnites from the Speeton section, were also incorporated into the dataset.

\section{Results}

Trace element and isotope data for the belemnites are presented in Table 1 and Figs 2 and 3. The belemnites sampled in this study were mostly translucent and retained the primary concentric banding that characterize belemnite rostra. A few samples (particularly rostra of Acroteuthis) showed irregular white areas around the margins which staining indicated to be Fe-rich and partial replacement by pyrite preferentially along 


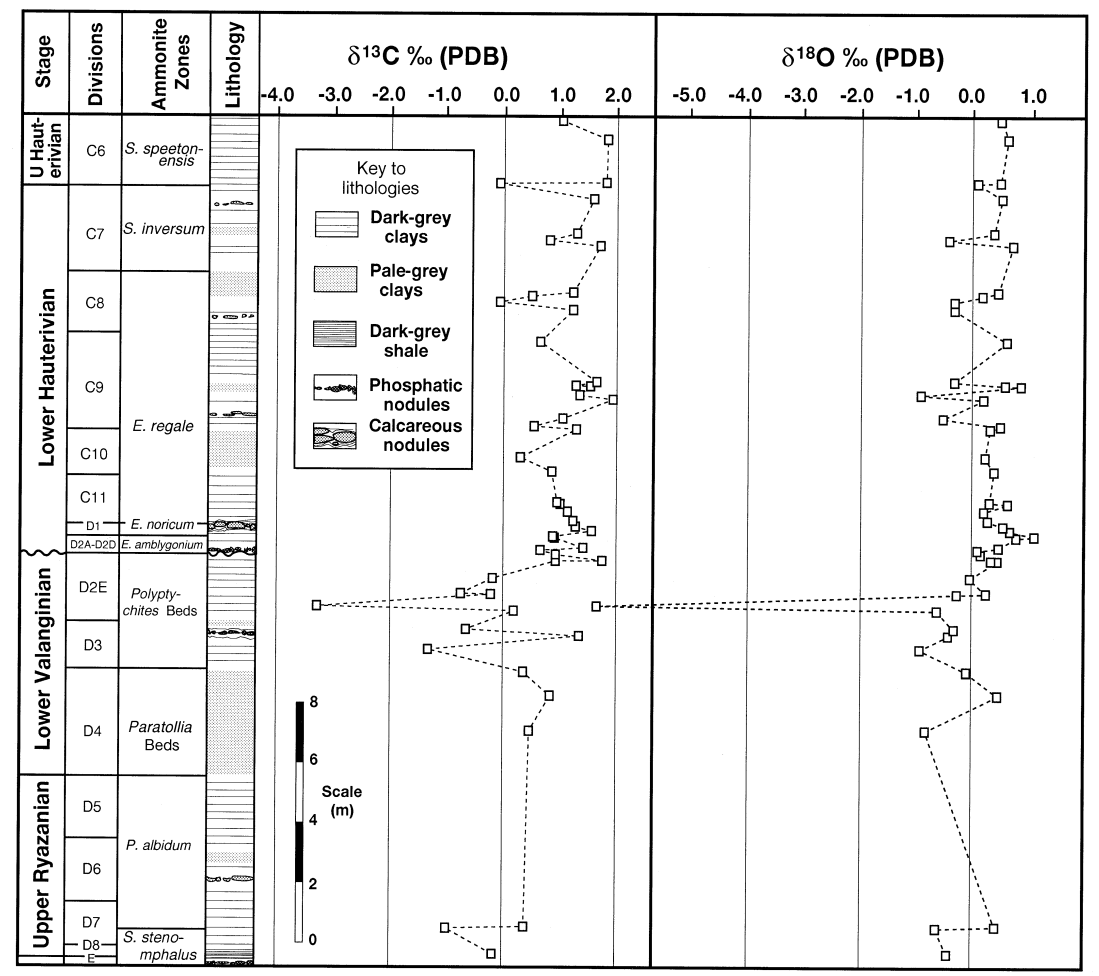

Fig. 2. $\delta^{18} \mathrm{O}$ (PDB) and $\delta^{13} \mathrm{C}(\mathrm{PDB})$ variation during the Ryazanian-Hauterivian interval at Speeton. Generalized sedimentary lithology and biostratigraphy from Neale (1960, 1962); Fletcher (1969); Rawson (1971) and Rawson et al. (1978). the concentric growth bands (Fig. 4). This may be due to the dissolution and subsequent cementation of unstable organic rich layers within the rostrum. Further, some belemnites show evidence of attack by various epifauna (serpulids, oysters and adherent foraminifera) and endofauna (possibly boring sponges)(see also Mitchell 1992; Price 1998). Because even subtle diagenetic alteration can potentially destroy any primary isotopic signal both $\mathrm{Mn}$ and Fe concentrations of the belemnites were determined to provide a further means to verify their state of preservation. Relatively low $\mathrm{Mn}(<100 \mathrm{ppm})$ and $\mathrm{Fe}$ $(<250 \mathrm{ppm})$ concentrations have been measured from modern organisms and can be assumed to reflect well-preserved shell material (e.g. Veizer 1983; Marshall 1992).

The low $\mathrm{Mn}(<100 \mathrm{ppm})$ and $\mathrm{Fe}(<250 \mathrm{ppm})$ values, recorded for most of the belemnites, in conjunction with the petrographic evidence, are thus consistent with minimal diagenetic alteration (see Marshall 1992; Price \& Sellwood 1997; Ditchfield 1997). The higher amounts of $\mathrm{Mn}$ and $\mathrm{Fe}$ and occasional outliers displaying more negative $\delta^{18} \mathrm{O}$ and $\delta^{13} \mathrm{C}$ values (Fig. 3) noted in some of the belemnites are regarded as an artefact of diagenetic alteration. These samples were excluded from the palaeotemperature calculations shown in Table 1 and Fig. 5.

Belemnite $\delta^{18} \mathrm{O}$ values are most negative $(-0.9 \%$ PDB) in the early Valanginian (Paratollia beds), whilst more positive $\delta^{18} \mathrm{O}$ values (up to $1.1 \%$ PDB) are present during the earliest Hauterivian (Endemoceras amyblygonium-lowest regale ammonite zones). The belemnite $\delta^{13} \mathrm{C}$ values also exhibit relatively negative values $(-1.4 \%$ PDB) during the early Valanginian and shift to considerably more positive values in the early Hauterivian, fluctuating about $+1.0 \%$ (PDB).

Calcite palaeotemperatures were calculated using the equation of Epstein et al. (1953) and Craig (1965), modified by Anderson \& Arthur (1983):

$$
T\left({ }^{\circ} \mathrm{C}\right)=16.0-4.14\left(\delta_{\mathrm{c}}-\delta_{\mathrm{w}}\right)+0.13\left(\delta_{\mathrm{c}}-\delta_{\mathrm{w}}\right)^{2}
$$

where $\delta_{\mathrm{c}}$ equals the oxygen isotopic composition of the calcite with respect to the PDB international standard and $\delta_{\mathrm{w}}$ equates to the oxygen isotopic composition of the water from which the calcite was precipitated with respect to the SMOW standard. In order to calculate palaeotemperatures, an assumption regarding the $\delta_{\mathrm{w}}$ of the Cretaceous ocean which is in part influenced by the presence or absence of polar ice during the Cretaceous, must be made. Seawater on Earth during periods that were free from major icecaps would have been isotopically lighter than at present and a $\delta_{\text {seawater }}$ of $-1.2 \%$, (PDB) (equivalent to $-1.0 \%$, SMOW), has been suggested as appropriate (Shackleton \& Kennett 1975). If small icecaps were present during the early Cretaceous, based upon inferences from sedimentological evidence (e.g. Frakes \& Francis 1988), the $\delta_{w}$ of a Cretaceous ocean may have been slightly heavier (Price et al. 1998).

\section{Interpretation}

\section{Oxygen isotopes and temperature signals}

Assuming that belemnites precipitate their shell carbonate in isotopic equilibrium with seawater (Lowenstam \& Epstein 1954), all year round and over a number of years, the observed isotopic variation is likely to be due to long-term temperature variation and/or variation in $\delta_{\text {seawater }}$. The estimation of $\delta_{\text {seawater }}$ values for Cretaceous times can be problematic because of uncertainties relating to the presence or absence of polar ice and the possibility of an equator-to-pole change in the isotopic composition of seawater (see Zachos et al. 1994; Price et al. 1996). Superimposed upon this potential variability is the possibility of locally concentrated isotopically light precipitation and/or freshwater runoff entering the marine system which could account for some of the observed fluctuations of the isotopic values. As the belemnite samples 
Table 1. Isotopic and elemental compositions of belemnite genera Acroteuthis and Hibolites (with calculated palaeotemperatures) analysed from Speeton

\begin{tabular}{|c|c|c|c|c|c|c|c|c|}
\hline Sample & $\begin{array}{l}\text { Approx. bed } \\
\text { position }(\mathrm{m})\end{array}$ & Stage & Species & $\begin{array}{c}\delta^{13} \mathrm{C} \\
(\mathrm{PDB})\end{array}$ & $\begin{array}{c}\delta^{18} \mathrm{O} \\
(\mathrm{PDB})\end{array}$ & $\begin{array}{c}T^{\circ} \mathrm{C} \\
\left(\delta_{\mathrm{w}}=-1\right)\end{array}$ & $\begin{array}{c}\mathrm{Fe} \\
(\mathrm{ppm})\end{array}$ & $\begin{array}{c}\mathrm{Mn} \\
(\mathrm{ppm})\end{array}$ \\
\hline Sp D7g-1* & 0.80 & Late Ryazanian? & Acroteuthis sp. & -0.22 & -0.37 & 13.4 & 196 & 22 \\
\hline SP1.63X & 1.63 & Late Ryazanian & Acroteuthis sp. & -1.05 & -0.57 & 14.3 & 189 & 10 \\
\hline Sp D7A* & 1.68 & Late Ryazanian & ? Acroteuthis sp. & 0.34 & 0.44 & 10.3 & 66 & 12 \\
\hline Sp D4C-2* & 7.97 & Early Valanginian & ? Acroteuthis sp. & 0.42 & -0.82 & 15.3 & 34 & 8 \\
\hline $\mathrm{D} 4 \mathrm{~A} \uparrow$ & 9.09 & Early Valanginian & Acroteuthis sp. & 0.79 & 0.47 & 10.2 & $<1$ & $<1$ \\
\hline $\mathrm{D} 3 \mathrm{D} \dagger$ & 9.84 & Early Valanginian & Acroteuthis sp. & 0.31 & -0.08 & 12.3 & 52 & $<\overline{1}$ \\
\hline SP1056X & 10.56 & Early Valanginian & Acroteuthis sp. & -1.38 & -0.86 & 15.4 & 34 & 14 \\
\hline $\mathrm{D} 3 \mathrm{~A} \dagger$ & 11.00 & Early Valanginian & Acroteuthis sp. & 1.30 & -0.42 & 13.6 & 186 & 7 \\
\hline SP1121 & 11.21 & Early Valanginian & Acroteuthis sp. & -0.71 & -0.29 & 13.1 & 108 & 10 \\
\hline SP1181 & 11.81 & Early Valanginian & Acroteuthis sp. & 0.14 & -0.60 & 14.4 & 111 & 15 \\
\hline SP1195: & 11.95 & Early Valanginian & Acroteuthis sp. & -3.35 & -6.63 & & 452 & 27 \\
\hline $\mathrm{D} 2 \mathrm{E} \dagger$ & 12.33 & Early Valanginian & Acroteuthis sp. & -0.27 & -0.25 & 13.0 & 5 & 7 \\
\hline SP1236 & 12.36 & Early Valanginian & A. (A.) acmonoides & -0.80 & 0.26 & 11.0 & 75 & 13 \\
\hline SP1341 & 13.41 & Early Hauterivian & A. (A.) paracmonoides $p$. & 0.88 & 0.46 & 10.2 & 232 & 12 \\
\hline Sp D2D* & 13.42 & Early Hauterivian & ? Acroteuthis sp. & 1.71 & 0.35 & 10.7 & 35 & 8 \\
\hline SP1362X & 13.62 & Early Hauterivian & A. (A.) paracmonoides $p$. & 0.88 & 0.17 & 11.3 & 42 & 8 \\
\hline SP1376X & 13.76 & Early Hauterivian & A. (A.) cf. acmonoides & 0.61 & 0.11 & 11.6 & 87 & 17 \\
\hline Sp D2B* & 13.84 & Early Hauterivian & ? Acroteuthis sp. & 1.37 & 0.48 & 10.2 & 35 & 9 \\
\hline $\mathrm{CB} 30(\mathrm{D} 1) \dagger$ & 14.16 & Early Hauterivian & H. jaculoides & 0.86 & 0.79 & 9.0 & 121 & $<1$ \\
\hline SP D1* & 14.20 & Early Hauterivian & ? Acroteuthis sp. & 0.83 & 1.11 & 7.8 & 56 & 10 \\
\hline SP1438X & 14.38 & Early Hauterivian & H. jaculoides & 1.52 & 0.68 & 9.4 & $<1$ & 7 \\
\hline SP1452X & 14.52 & Early Hauterivian & Hibolites sp. & 1.23 & 0.56 & 9.9 & $<1$ & 6 \\
\hline SP1470 & 14.70 & Early Hauterivian & H. jaculoides & 1.19 & 0.29 & 10.9 & 188 & 10 \\
\hline SP1499 & 14.99 & Early Hauterivian & H. jaculoides & 1.09 & 0.22 & 11.2 & 199 & 18 \\
\hline SP1524 & 15.24 & Early Hauterivian & H. jaculoides & 0.96 & 0.64 & 9.6 & 169 & 9 \\
\hline SP1529 & 15.29 & Early Hauterivian & H. jaculoides & 0.90 & 0.32 & 10.8 & 199 & 19 \\
\hline SP1626 & 16.26 & Early Hauterivian & Hibolites sp. & 0.81 & 0.40 & 10.1 & 165 & 9 \\
\hline SP1671 & 16.71 & Early Hauterivian & Hibolites sp. & 0.25 & 0.24 & 11.1 & 229 & 29 \\
\hline SP1761 & 17.61 & Early Hauterivian & H. jaculoides & 1.24 & 0.33 & 10.7 & 154 & 10 \\
\hline SP1771 & 17.71 & Early Hauterivian & H. jaculoides & 0.49 & 0.51 & 10.0 & 119 & 9 \\
\hline SP1871 & 18.71 & Early Hauterivian & Hibolites sp. & 1.30 & -0.89 & 15.5 & 86 & $<1$ \\
\hline SP1900† & 19.00 & Early Hauterivian & Hibolites sp. & 1.49 & 0.87 & 8.7 & 19 & $<1$ \\
\hline $\mathrm{SP} 19.02 \dagger$ & 19.02 & Early Hauterivian & Hibolites sp. & 1.23 & 0.59 & 9.7 & 12 & $<1$ \\
\hline SP1914 & 19.14 & Early Hauterivian & Hibolites sp. & 1.60 & -0.27 & 13.1 & 102 & $<1$ \\
\hline SP2042 & 20.42 & Early Hauterivian & Hibolites sp. & 0.60 & 0.62 & 9.7 & 169 & 8 \\
\hline SP2144 & 21.44 & Early Hauterivian & H. jaculoides & 1.18 & -0.34 & 13.3 & 177 & 20 \\
\hline SP2169 & 21.69 & Early Hauterivian & H. jaculoides & -0.12 & -0.25 & 13.0 & 145 & 21 \\
\hline SP2188X & 21.88 & Early Hauterivian & H. jaculoides & 0.45 & 0.19 & 11.3 & $<1$ & $<1$ \\
\hline SP2200 & 22.00 & Early Hauterivian & Hibolites sp. & 1.18 & 0.46 & 10.3 & 113 & 10 \\
\hline Sp C7F* & 23.49 & Early Hauterivian & ? Hibolites sp. & 1.66 & 0.72 & 9.3 & 37 & 8 \\
\hline SP2367 & 23.67 & Early Hauterivian & H. jaculoides & 0.76 & -0.39 & 13.5 & 209 & 10 \\
\hline $\mathrm{C} 7 \mathrm{E} \dagger$ & 23.90 & Early Hauterivian & H. jaculoides & 1.24 & 0.39 & 10.5 & 33 & $<1$ \\
\hline $\mathrm{C} 7 \dagger$ & 25.00 & Early Hauterivian & H. jaculoides & 1.54 & 0.53 & 10.0 & 27 & $<1$ \\
\hline SP2550 & 25.50 & Late Hauterivian & Hibolites sp. & -0.13 & 0.10 & 11.6 & 172 & 16 \\
\hline Sp C6-3* & 25.53 & Late Hauterivian & ? Hibolites sp. & 1.76 & 0.50 & 10.1 & 36 & 8 \\
\hline Sp C6-1* & 26.91 & Late Hauterivian & ? Hibolites sp. & 1.78 & 0.63 & 9.6 & 53 & 8 \\
\hline $\mathrm{C} 6 \dagger$ & 27.50 & Late Hauterivian & H. jaculoides & 0.98 & 0.53 & 10.0 & $<1$ & $<1$ \\
\hline
\end{tabular}

*Data from Jones (1992) \& Jones et al. (1994).

†Oxygen and carbon isotopes analyses carried out at Bochum, trace element analysis at Plymouth.

\$Deemed diagenetically altered and hence not used further in this study.

were derived from a marine system (based upon the presence of a fully marine fauna including ammonites), the latter two influences upon the isotopic variability are likely to be minimal and temperature will be the major factor influencing the observed oxygen isotopes. Some studies (e.g. Spaeth et al. 1971) have reported relatively large ranges, up to $2 \%$, of both $\delta^{18} \mathrm{O}$ and $\delta^{13} \mathrm{C}$ within individual belemnite rostra. More recently, Podlaha et al. (1998) also note a similar internal range, but relate such variability to diagenetic overprinting. Furthermore, as both Anderson et al. (1994) and Podlaha et al. (1998) report a relatively large range of oxygen and carbon isotope values obtained from well-preserved belemnites from well-constrained horizons, Fig. 5 displays both $\delta^{13} \mathrm{C}$ and estimated palaeotemperatures plotted using a three-point moving average to exclude over-interpretation of possible outliers. 


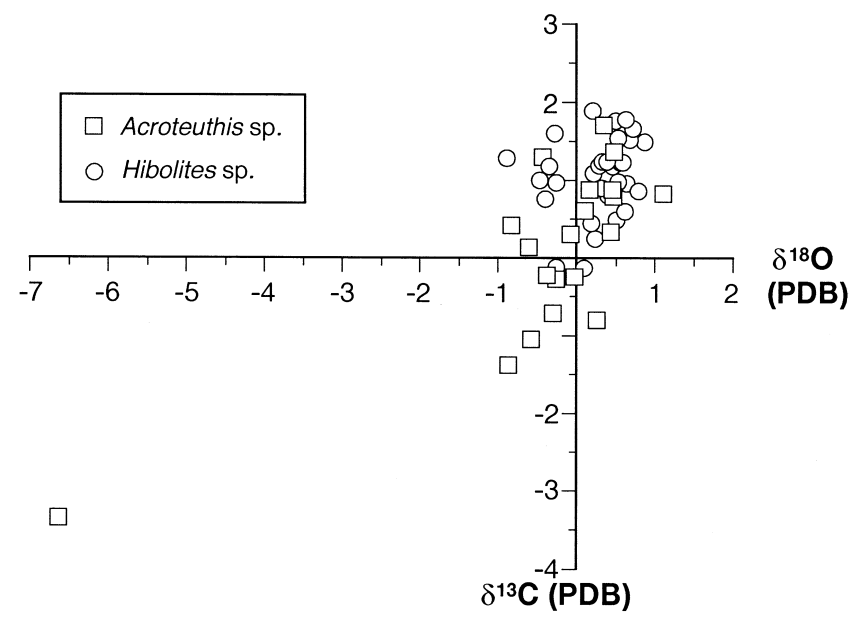

Fig. 3. Cross-plot of $\delta^{18} \mathrm{O}$ and $\delta^{13} \mathrm{C}$ values of belemnite samples from Speeton.

Using a seawater $\delta_{\mathrm{w}}$ value of $-1.0 \%$ (SMOW), calculated palaeotemperatures show a variation during the late Ryazanian-early Valanginian, ranging from 10 to $15^{\circ} \mathrm{C}$ (Table 1, Fig. 5). The warmest temperatures observed in this interval are similar to those calculated from stable isotopic analysis of belemnites from the latest Albian Red Chalk (also exposed at Speeton), which represents a time closer to the Cretaceous climatic optimum (Price 1998). Similar temperatures $\left(10-11.5^{\circ} \mathrm{C}\right)$ occur within the earliest Hauterivian (amblygonium ammonite zone), followed by rapid cooling where estimated temperatures drop to $<9^{\circ} \mathrm{C}$. During the remainder of the Hauterivian temperatures fluctuated considerably and rose to a maximum of $15^{\circ} \mathrm{C}$. These temperatures compare favourably with estimates made by Hendry et al. (1996) who suggested a possible range of $c .8-18^{\circ} \mathrm{C}$ during the early Hauterivian, based upon the isotopic analysis of early marine calcite cements from the North Sea. If the coolest temperatures of the lowermost Hauterivian at Speeton (located at a palaeolatitude of c. 40$45^{\circ} \mathrm{N}$ ) are extrapolated to northern polar regions, through a 'normal' latitudinal range (e.g. Pirrie \& Marshall 1990) they would suggest sub-freezing temperatures in these regions.

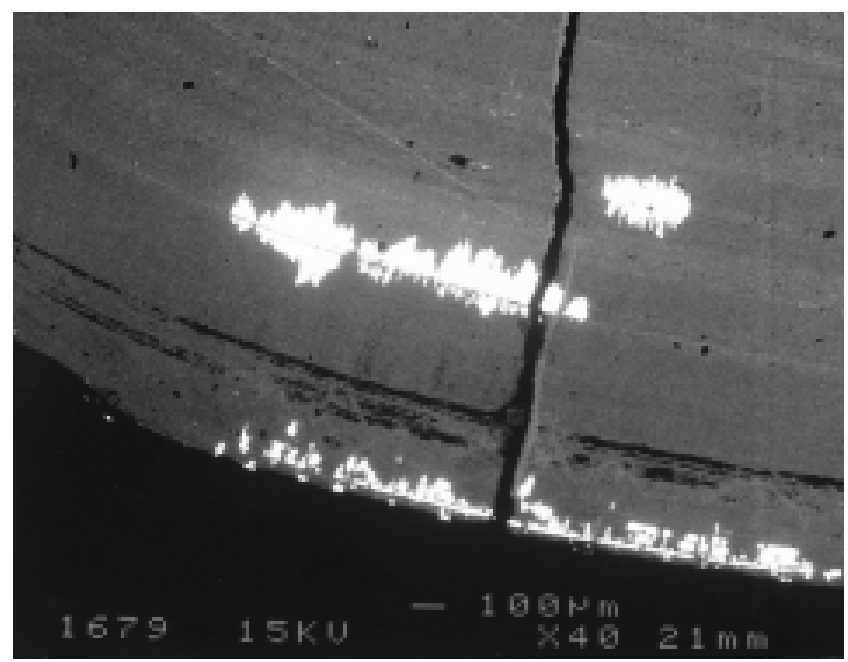

Fig. 4. Backscattered SEM photomicrograph of partial replacement by pyrite preferentially along the concentric growth band within a belemnite rostrum (Acroteuthis sp.) (Sample SP1.63X). Scale bar is $100 \mu \mathrm{m}$.
A number of other independent sources of data may also point to at least seasonally frigid polar conditions within this essentially warm and possibly equable period of Earth history. During the early Valanginian and the mid HauterivianBarremian, Weissert \& Lini (1991) infer possible cooling events or icehouse climates associated with episodes of decelerated carbon cycling. A relatively cold early-mid-Valanginian has also been proposed by Ditchfield (1997) who suggested mean palaeotemperatures of $8.1^{\circ} \mathrm{C}$ based on the isotopic analysis of endemic belemnites from Svalbard. If belemnites were possibly necto-benthonic in habitat as suggested by Anderson et al. (1994), it would be inappropriate to extrapolate such cool temperatures to the pole in order to infer surface temperatures for these regions. However, it is clear from other isotopic studies (e.g. Barrera et al. 1987; Pirrie \& Marshall 1990; Price \& Sellwood 1997) that belemnites were more likely to be nektonic and lived in variable depth-related habitats and are likely to represent minimum estimates of sea surface temperature.

It is of note that the presence of reef facies, consisting of bryozoans, corals, serpulids and crinoids of earliest Hauterivian age (amblygonium ammonite zone) in the shallow coastal areas of the southwest part of the NW German basin, have been considered to allude to much warmer conditions at this time (Mutterlose 1992). Comparison with Fig. 5, however, shows that this time is characterized by the coolest palaeotemperatures encountered in this study. The lowermost Hauterivian (amblygonium-noricum ammonite zones) at Speeton are highly condensed and contain a number of stratigraphic gaps (Fig. 2) and the ammonite zones in this part of the succession are represented by just a few tens of centimetres of sediment. Hence, it is likely that part of the potential isotopic record is absent. However, to assume that it is a warm isotopic palaeotemperature signal that is missing is unjustified.

\section{Carbon isotope variation}

The carbon isotope values (Fig. 2) show a clear trend through the studied section. Lightest $\delta^{13} \mathrm{C}$ values occur during the early Valanginian (Paratollia-Polyptychites beds) and are more positive during the early Hauterivian interval. This trend is not an artefact of isotopic analysis of two different belemnite genera as the Hauterivian part of the curve is based upon the analysis of both Acroteuthis and Hibolites, seen in terms of an overlap of data in Fig. 3 (cf. Saelen \& Karstang 1989). Such an abrupt change in $\delta^{13} \mathrm{C}$ values, a characteristic feature of a stratigraphic break, may be related to the Valanginian-early Hauterivian positive carbon isotope event observed by Weissert (1989) and Lini et al. (1992). If so, the data suggests that the $\delta^{13} \mathrm{C}$ excursion may not necessarily be restricted to just Tethyan sequences.

The belemnite-derived $\delta^{13} \mathrm{C}$ values are consistently more negative (by $c .1 \%$ ) than the Tethyan values of Lini et al. (1992). This offset may be accounted for as the Tethyan sequences are dominated by coccoliths which calcify in the photic zone (which is relatively enriched in ${ }^{13} \mathrm{C}$, see Berger \& Vincent 1986; Marshall 1992), whereas belemnites were more likely to have grown and calcified at more variable depthrelated habitats. Lini et al. (1992) assert that the positive shift in carbon isotope values represents an episode of 'greenhouse' conditions and propose a model linking carbon isotope trends with sea level changes via a complex interplay between volcanism, climate, weathering, increased nutrient availability 


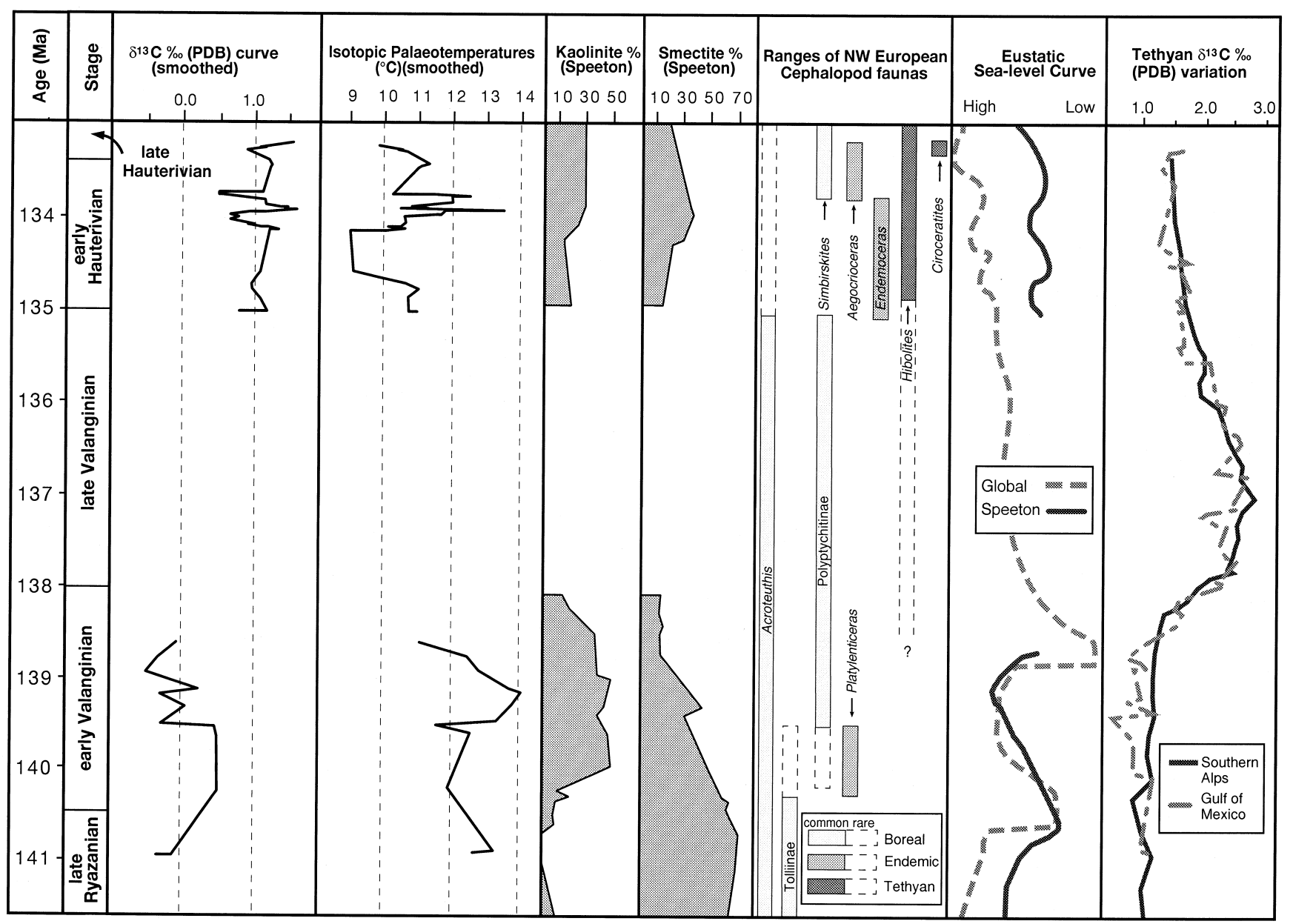

Fig. 5. Chronostratigraphic chart of the Ryazanian-Hauterivian interval, showing smoothed (three point moving average) palaeotemperature and $\delta^{13} \mathrm{C}$ profiles, the global eustatic sea level curve from Haq et al. (1987), and local sea level variation from Ruffell (1991). Clay mineralogy from Ruffell \& Batten (1990) and Hallam et al. (1991). Tethyan pelagic carbon isotope variation from Cotillon \& Rio (1984) and Lini et al. (1992). Ages, from Harland et al. (1990), have been determined according to position within each ammonite zone and assigning equal duration to each ammonite zone (see Jones et al. 1994).

due to higher runoff rates, and carbon burial. As noted above, cooling events or icehouse climates were inferred by Weissert \& Lini (1991) to be associated with episodes of decelerated carbon cycling and hence relatively light carbon isotope values. The Upper Valanginian at Speeton is absent and the lowermost Hauterivian is highly condensed. These horizons span a time interval coincident with the most positive carbon values recorded by Weissert (1989) and Lini et al. (1992). Recent isotopic analyses of belemnites from northern Germany (Podlaha et al. 1998) do show, however, positive $\delta^{13} \mathrm{C}$ values $\left(0.1-2.3 \%\right.$ 。 PDB) from the late Valanginian and $\delta^{18} \mathrm{O}$ values which range from 0.6 to $-1.7 \%$ ( $\mathrm{PDB}$ ). The most negative $\delta^{18} \mathrm{O}$ values correspond to palaeotemperatures as warm as $19^{\circ} \mathrm{C}$ (assuming a $\delta_{\text {seawater }}$ value of $-1.0 \%$, SMOW). Hence the coincidence of a broad period of warmth, albeit with short term cooler events, commencing in late early Valanginian and possibly continuing into the late Valanginian may suggest that the inferences of Lini et al. (1992) have some validity. Chumakov (1995) has recently, however, suggested that icehouse interludes based upon carbon isotope fluctuations are unconvincing and even if the negative excursions were related to cooling events, there is no reason to consider them strong enough to have resulted in glaciation. It is of note that the lightest carbon isotopic values from this study (occurring during the early Valanginian) are coincident with the warmest palaeotemperatures. That the positive shift in carbon isotope values from the studied interval and those of the Lini et al. (1992) appear coincident with the inferred rise in global sea level of Haq et al. (1987) (albeit with some differences in the early Valanginian, see below), may suggest that sea level change is an important control upon $\delta^{13} \mathrm{C}$ variation. Whether the sea-level rise is symptomatic or simply coincidental with a rise in temperatures remains not fully substantiated.

A number of authors (e.g. Kemper 1987; Mutterlose 1992; Kutek \& Marcinowski 1996) have also suggested that the latest Valanginian in Europe and high northern latitudes was a time of warmth (or high sea levels), based upon the presence of warm water faunas and the absence of dropstones and glendonites. Contrary evidence has been used to infer cooler periods during intervals within the Ryazanian, the Valanginian and the late Hauterivian in Europe (Mutterlose 1992) and seasonally sub-freezing temperatures at higher palaeolatitudes (Kemper 1987; Frakes \& Francis 1988). The reliability of this dropstone evidence and its validity in demonstrating icehouse interludes within the Cretaceous has recently been questioned and a number of alternatives to ice-transport by which 
dropstones may be introduced to host sediments have been proposed (Bennett \& Doyle 1996). As the palaeotemperature variation outlined in Fig. 5 corresponds in part to the sedimentological evidence for cool climates during the early Cretaceous this accordingly may partially substantiate the inferences from the dropstone and glendonite evidence.

\section{Clay minerals and sea-level variation}

Clay mineralogy data, obtained from the Speeton Clay exposed in Yorkshire (Ruffell \& Batten 1990; Hallam et al. 1991; Knox 1991), shows an increase in kaolinite and a synchronous decrease in smectite from the Ryazanian through the Lower Valanginian (Fig. 5). This pattern is considered to be a result of increases in humidity in the continental source area and has been tentatively correlated with a warmer climate (e.g. Ruffell \& Batten 1990; Frakes et al. 1992; Price et al. 1998). The observed variation in clay mineralogy is consistent with the isotopically derived palaeotemperatures from Speeton with the warmest temperatures occurring in the early Valanginian, coincident with the highest amounts of kaolinite.

Smectite and kaolinite are present in similar quantities within the Lower Hauterivian, and have been interpreted as a result of short-term climate oscillations between humid and arid phases (Ruffell \& Batten 1990) consistent with fluctuating temperatures as shown in Fig. 5. The apparent cold event with temperatures dropping to $<9^{\circ} \mathrm{C}$ during the lowermost Hauterivian might be considered to be associated with an extremely arid climate if the above reasoning is correct. Significantly, Ruffell \& Batten (1990) highlighted the Barremian as potentially the phase of greatest aridity, but alluded to arid climates being in existence as early as the Valanginian-Hauterivian boundary and as late as the early Aptian. Later, Ruffell \& Rawson (1994) linked arid climate phases to potential periods of cold climate. Taken together, the two models suggest a cooler more arid Hauterivian compared to a warmer more humid Valanginian. Such inferred shortterm alternations in the climate and hydrology of the continental source area could, through changes in precipitation, runoff and evaporation, account for some of the observed short-term oxygen and carbon isotope variability.

Comparison of the palaeotemperatures and the $\delta^{13} \mathrm{C}$ profile with the local sea-level curve of Ruffell (1991) and global sea level curve of Haq et al. (1987) also shows a reasonable agreement. The warm palaeotemperatures observed in the early Valanginian coincide with a sea-level highstand and the cyclic nature of short term sea-level rises and falls during the Hauterivian might also be mirrored in fluctuating temperatures (Fig. 5). Such an observation may suggest that temperature is a factor influencing sea-level variation during the early Cretaceous, possibly related to the growth and decay of polar ice (see Haq et al. 1987; Valdes et al. 1995; Price et al. 1998; Stoll \& Schrag 1996) although the apparent earliest Hauterivian cold event does not appear to correlate with a significant sea-level low.

As noted above, the observed positive shift in carbon isotope values from the studied interval appears to be coincident with the albeit conjectural inferred rise in global sea level commencing in the late-early Valanginian of Haq et al. (1987). Many previous studies (e.g. Weissert 1989; Weissert \& Lini 1991; Jenkyns et al. 1994; Voigt \& Hilbrecht 1997) have also linked transgressions with positive $\delta^{13} \mathrm{C}$ shifts (although the opposite has recently been proposed by Gröcke et al. (1999) based upon carbon isotope variation in Aptian fossil wood fragments). It has been suggested that regressive episodes, if accompanied by erosion, seaward transport and oxidation of carbon-rich deposits, would clearly be registered by a pronounced negative shift in the $\delta^{13} \mathrm{C}$ profile (Jenkyns et al. 1994; Voigt \& Hilbrecht 1997). Such a mechanism could account for the relatively negative values observed during the late Ryazanian and earliest Valanginian (Fig. 2) which are coincident with a sea-level low (Fig. 5). A shift to more positive $\delta^{13} \mathrm{C}$ values is not observed during the following transgression in the early Valanginian, possibly related to a continuance of the effects of increased ${ }^{12} \mathrm{C}$ input into the ocean carbon reservoir.

\section{Faunal changes}

Throughout the early Cretaceous section at Speeton there is an alternation of Boreal and Tethyan genera. The belemnitederived palaeotemperature data may also help elucidate controls upon provinciality. As noted above, the $\mathrm{D}$ beds at Speeton (Upper Ryazanian-lowermost Hauterivian) contain the Boreal belemnite genus Acroteuthis, whilst the $\mathrm{C}$ beds (Lower-Upper Hauterivian) are dominated by Hibolites, a characteristically Tethyan genus which periodically migrated northwards during both the Jurassic and Cretaceous (Rawson 1973). There is only a very limited overlap of forms: for example a few specimens of Acroteuthis occur in the early $\mathrm{C}$ beds (Hibolites beds) at Speeton (Rawson 1973; Mutterlose et al. 1987; Mitchell 1992). The primary control upon the alternation of Tethyan and Boreal belemnites seen in the Speeton section may have thus been ocean temperature (Rawson 1973; Stevens 1973). However, the trend in the palaeotemperature curve suggests a warm climate during Valanginian and a fluctuating and often cooler climate during the Hauterivian. This would appear inconsistent with the belemnite occurrence (Fig. 5). Paradoxically, a Tethyan influence and hence warmer climate during the Hauterivian could be inferred from the belemnite distribution pattern. However, in periods of high sea level, such as the late Valanginian (Haq et al. 1987; Ruffell 1991) greater migration of belemnites may have been possible, because of the stabilizing influence of increased water depth (Rawson 1973; Doyle 1987; Mutterlose 1992) and the opening up of potential seaways (Fig. 1). Thus, a Tethyan population of belemnites was provided with an opportunity to migrate during the late Valanginian and become established in an essentially Boreal area by Hauterivian times. Mutterlose (1988) suggests that the Tethyan genus Hibolites was able to migrate into a realm other than the one in which they originated as they were eurythermal belemnites i.e. tolerant of a range of ocean temperatures.

\section{Conclusions}

Oxygen isotope values determined from well-preserved belemnites indicate warm palaeotemperatures $\left(c .12-15^{\circ} \mathrm{C}\right)$ for much of the Valanginian whilst cooler temperatures $\left(<9^{\circ} \mathrm{C}\right)$ are inferred for the lowermost Hauterivian. If these coolest temperatures are extrapolated through a 'normal' latitudinal range to northern polar regions they would suggest sub-freezing temperatures in these areas. Such an observation may suggest that frigid polar conditions, which have also been inferred from (recently questioned) sedimentological evidence, have some validity. It must be remembered that, because of the 
condensed nature of parts of the sedimentary succession at Speeton, part of the isotopic record is likely to be absent.

The episodes of warm and cool temperatures correlate with sea level variation and to changes in kaolinite and smectite which have been considered to reflect humid and arid phases of climate. Such a correlation lends credence to clay mineral changes at Speeton to being climatically controlled.

The palaeotemperature record appears to contradict that of the cephalopod faunas, with a Tethyan influx during a cool period (i.e. the early Hauterivian). However, we note that this was a transgressive phase and thus some cephalopod taxa may be less sensitive to temperature than to water column stability and land barriers.

The carbon isotope curve obtained from the belemnites shows a comparable pattern to coeval Tethyan carbon isotope profiles, albeit with somewhat differing absolute values. The data support earlier models of carbon isotope variation, in that positive excursions are associated with an inferred global rise in sea level.

Isotopic analyses were carried out at the Environmental Engineering Research Centre, The Queen's University of Belfast and we are particularly grateful for the assistance of N. Ogle. We express our thanks also for the isotope data from the Ruhr-Universität Bochum and to J. P. Hendry and H. Strauss who made many useful critical comments on an earlier version of this manuscript. Constructive reviews by L. A. Frakes and J. D. Hudson, in addition to the thorough editorial comments by D. Pirrie helped greatly improve an earlier version of the manuscript.

\section{References}

Anderson, T.F. \& Arthur, M.A. 1983. Stable isotopes of oxygen and carbon and their application to sedimentologic and environmental problems. In: Arthur, M.A., Anderson, T.F., Kaplan, I.R., Veizer, J. \& LAND, L.S (eds) Stable isotopes in Sedimentary Geology. Society of Economic Paleontologists and Mineralogists Short Course Notes, 10, 1.1-1.151.

—, Popp, B.N., Williams, A.C., Ho, L.Z. \& Hudson, J.D. 1994. The stable isotopic records of fossils from the Peterborough Member, Oxford Clay Formation (Jurassic), UK: palaeoenvironmental considerations. Journal of the Geological Society, London, 151, 125-138.

Barrera, E., Huber, B.T., Savin, S.M. \& Webb, P.N. 1987. Antarctic marine temperatures: late Campanian through early Paleocene. Paleoceanography, 2, 21-47.

BennetT, M.R. \& Doyle, P. 1996. Global cooling inferred from dropstones in the Cretaceous-Fact or wishful thinking. Terra Nova, 8, 182-185.

Berger, W.H. \& Vincent, E. 1986. Deep-sea carbonates: reading the carbon-isotope signal. Geologisches Rundschau, 75, 249-269.

Chumakov, N.M. 1995. The problem of the warm biosphere. Stratigraphy and Correlation, 3, 205-215.

Cotillon, P. \& Rio, M. 1984. Cyclic sedimentation in the Cretaceous of DSDP site 535 and 540 (Gulf of Mexico), 534 (central Atlantic) and the Vocontian Basin France. In: Buffler, R.T., Schlager W. eT AL. (eds) Initial Reports of the Deep Sea Drilling Project. US Government Printing Office, Washington, 77, 339-376.

Craig, H. 1965. The measurement of oxygen isotope palaeotemperatures. In: Tongiorgi E. (ed.) Stable Isotopes in oceanographic studies and palaeotemperatures. Consiglio Nazionale delle Richerche, Laboratorio di Geologia Nucleare, Pisa, 161-182.

Dickson, J.A.D. 1966. Carbonate identification and genesis as revealed by staining. Journal of Sedimentary Petrology, 36, 491-505.

DitchField, P.W. 1997. High northern palaeolatitude Jurassic-Cretaceous palaeotemperature variation: New data from Kong Karls Land, Svalbard. Palaeogeography Palaeoclimatology Palaeoecology, 130, 163-175.

Doyle, P. 1987. Lower Jurassic-Lower Cretaceous belemnite biogeography and the development of the Mesozoic Boreal realm. Palaeogeography Palaeoclimatology Palaeoecology, 61, 237-254.

Epstein, S., Buchsbaum, R., Lowenstam, H.A. \& Urey, H.C. 1953. Revised carbonate-water isotopic temperature scale. Geological Society of America Bulletin, 64, 1315-1326.
Fletcher, B.N. 1969. A lithological subdivision of the Speeton Clay C Beds (Hauterivian), East Yorkshire. Proceedings of the Yorkshire Geological Society, 37, 323-327.

Frakes, L.A. \& Francis, J.E. 1988. A guide to Phanerozoic cold polar climates from high latitude ice-rafting in the Cretaceous. Nature, 333, 547-549.

- - \& Syktus, J.I. 1992. Climate Modes of the Phanerozoic. Cambridge University Press, Cambridge.

Gröcke, D., Hesselbo, S.P. \& JenKyns, H.C. 1999. Carbon-isotope composition of Lower Cretaceous fossil wood: Ocean-atmosphere chemistry and relation to sea-level change. Geology, 27, 155-158.

Hallam, A. 1984. Distribution of fossil marine invertebrates in relation to climate. In: Brenchley, P.J. (ed.) Fossils and Climate. Wiley, London, $107-125$.

— Grose, J.A. \& Ruffell, A.H. 1991. Palaeoclimatic significance of changes in clay mineralogy across the Jurassic-Cretaceous boundary in England and France. Palaeogeography Palaeoclimatology Palaeoecology, 81, 173-187.

HaQ, B.U., Hardenbohl, J. \& Vail, P.R. 1987. Chronology of fluctuating sea-levels since the Triassic. Science, 235, 1156-1167.

Harland, W.B., Armstrong, R.L., Cox, A.V., Craig, L.E., Smith, A.G. \& Smith, D.G. 1990. A geologic time scale 1989. Cambridge University Press, Cambridge.

Hendry, J.P., Trewin, N.H. \& Fallick, A.E. 1996. Low-Mg calcite marine cement in Cretaceous turbidites: origin, spatial distribution and relationship to seawater chemistry. Sedimentology, 43, 877-900.

Jenkyns, H.C. \& Clayton, C.J. 1997. Lower Jurassic epicontinental carbonates and mudstones from England and Wales: chemostratigraphic signals and the early Toarcian anoxic event. Sedimentology, 44, 687-706.

—, Gale, A.S. \& Corfield, R.M. 1994. Carbon- and oxygen-isotope stratigraphy of the English Chalk and Italian Scaglia and its palaeoclimatic significance. Geological Magazine, 131, 1-34.

JoNES, C.E. 1992. Strontium isotopes in Jurassic and early Cretaceous seawater. $\mathrm{PhD}$ thesis, University of Oxford.

—, Jenkyns, H.C., Coe, A.L. \& Hesselbo, S.P. 1994. Strontium isotopic variations in Jurassic and Cretaceous seawater. Geochimica et Cosmochimica Acta, 58, 3061-3074.

Kemper, E. 1987. Das Klima der Kreide-Zeit. Geologisches Jahrbuch, A96, 5-185.

KNox, R.W.O'B. 1991. Ryazanian to Barremian mineral stratigraphy of the Speeton Clay in the UK southern North Sea Basin. Proceedings of the Yorkshire Geological Society, 48, 255-264.

Kutek, J. \& Marcinowski, R. 1996. Faunal changes in the Valanginian of Poland: tectonic or eustatic control? Mitteilungen aus dem Geologisch-Paläontologischen Institut der Universität Hamburg, 77, 83-88.

Lamplugh, G.W. 1889. On the subdivisions of the Speeton Clay. Quarterly Journal of the Geological Society of London, 45, 575-618.

Lini, A., Weissert, H. \& ERbA, E. 1992. The Valanginian isotope event: a first episode of greenhouse climate conditions during the Cretaceous. Terra Nova, 4, 374-384.

Lowenstam, H.A. \& Epstein, S. 1954. Paleotemperatures of the post-Albian Cretaceous as determined by the oxygen isotope method. Journal of Geology, 62, 207-248.

Marshall, J.D. 1992. Climatic and oceanographic isotopic signals from the carbonate rock record and their preservation. Geological Magazine, 129, $143-160$.

Mitchell, S.F. 1992. The belemnite faunal changes across the HauterivianBarremian boundary in north-east England. Proceedings of the Yorkshire Geological Society, 49, 129-134.

Mutterlose, J. 1988. Migration and evolution patterns in Upper Jurassic and Lower Cretaceous Belemnites. In: Weidmann, J. \& Kullmann J. (eds) Cephalopods-Present and Past. Schweizerbart'sche Verlagbuchhandlung, Stuttgart, 525-537.

1992. Migration and evolution patterns of floras and faunas in marine early Cretaceous sediments of NW Europe. Palaeogeography Palaeoclimatology Palaeoecology, 94, 261-282.

1997. Lower Cretaceous. In: Mutterlose, J., Wippich, M.G.E. \& Geisen, M. (eds) Cretaceous depositional environments of NW Germany. Bochumer geologische und geotechnische Arbeiten, 46, 7-12.

—, Pinckney, G. \& Rawson, P.F. 1987. The belemnite Acroteuthis in the Hibolites beds (Hauterivian-Barremian) of North-West Europe. Palaeontology, 30, 635-645.

Neale, J.W. 1960. The subdivision of the Upper D beds of the Speeton Clay of Speeton, East Yorkshire. Geological Magazine, 97, 353-362.

1962. Ammonoidea from the early D beds (Berriasian) of the Speeton Clay. Palaeontology, 5, 272-296. 
Pirrie, D. \& Marshall, J.D. 1990. High-paleolatitude late Cretaceous paleotemperatures-new data from James Ross Island, Antarctica. Geology, 18, 31-34.

Podlaha, O.G., Mutterlose, J. \& Veizer, J. 1998. Preservation of $\delta^{18} \mathrm{O}$ and $\delta^{13} \mathrm{C}$ in belemnite rostra from the Jurassic/Early Cretaceous successions. American Journal of Science, 298, 324-347.

PrICE, G.D. 1998. Isotopic variation in fossils and matrix of the Cretaceous Red Chalk at Speeton and South Ferriby, Yorkshire, England. Proceedings of the Yorkshire Geological Society, 52, 107-112.

— \& Sellwood, B.W. 1997. Warm palaeotemperatures from high late Jurassic palaeolatitudes (Falkland Plateau): ecological, environmental or diagenetic controls? Palaeogeography Palaeoclimatology Palaeoecology, 129, 315-327.

— Sellwood, B.W. \& Pirrie, D. 1996. Middle-late Cretaceous climate of the southern high latitudes: Stable isotopic evidence for minimal equator-topole thermal gradients-Discussion. Geological Society of America Bulletin, 108, 1192-1193.

— VAldes, P.J. \& Sellwood, B.W. 1998. A comparison of GCM simulated Cretaceous Greenhouse and Icehouse climates: Implications for the sedimentary record. Palaeogeography Palaeoclimatology Palaeoecology, 142, 123-138.

Rawson, P.F. 1971. The Hauterivian (Lower Cretaceous) biostratigraphy of the Speeton Clay of Yorkshire, England. Newletters on Stratigraphy, 1, 61-76.

- 1973. Lower Cretaceous (Ryazanian-Barremian) marine connections and cephalopod migrations between the Tethyan and Boreal Realms. In: CASEY, R. \& Rawson, P.F. (eds) The Boreal Lower Cretaceous. Geological Journal Special Issue, 5, 131-145.

—, Currey, D., Dilley, F.C., Hancock, J.M., Kennedy, W.J., Neale, J.W., Wood, C.J. \& Worssam, B.C. 1978. A correlation of Cretaceous rocks in the British Isles. Geological Society of London Special Reports, 9.

Ruffell, A.H. 1991. Sea-level events during the early Cretaceous in Western Europe. Cretaceous Research, 12, 527-551.

— \& BAtTen, D.J. 1990. The Barremian-Aptian arid phase in WesternEurope. Palaeogeography Palaeoclimatology Palaeoecology, 80, 197-212.

— \& Rawson, P.F. 1994. Palaeoclimate control on sequence stratigraphic patterns in the late Jurassic to mid-Cretaceous, with a case-study from eastern England. Palaeogeography Palaeoclimatology Palaeoecology, 110, $43-54$.

Saelen, G. \& Karstang, T.V. 1989. Chemical signatures of belemnites. Neues Jahrbuch für Geologie und Paläontologie Abhandlungen, 177, 333-346.
Shackleton, N.J. \& KenNeTt, J.P. 1975. Paleotemperature history of the Cenozoic and the initiation of Antarctic glaciation: Oxygen and carbon isotope analyses in DSDP sites 277, 279 and 281. In: KenNeTt, J.P., Houtz, R.E. ET AL. (eds) Initial Reports of the Deep Sea Drilling Project Washington: U.S. Government Printing Office. 29, 743-756.

Smith, A.G., Smith, D.G. \& Funnell, B.M. 1994. Atlas of Mesozoic and Cenozoic Coastlines. Cambridge University Press.

Spaeth, E., Hoeffs, J. \& Vetter, U. 1971. Some aspects of isotopic composition of belemnites and related paleotemperatures. Geological Society of America Bulletin, 82, 3139-3150.

Stevens, G.R. 1973. Cretaceous Belemnites. In: Hallam, A. (ed.) Atlas of Paleobiogeography. Elsevier Amsterdam London, 385-401.

Stoll, H.M. \& SCHRaG, D.P. 1996. Evidence of glacial control of rapid sea level changes in the early Cretaceous. Science, 272, 1771-1774.

Urey, H.C., Lowenstam, H.A., Epstein, S. \& McKinney, C.R. 1951. Measurement of paleotemperatures and temperatures of the Upper Cretaceous of England, Denmark, and the southeastern United States. Geological Society of America Bulletin, 62, 399-416.

Valdes, P.J., Sellwood, B.W. \& Price, G.D. 1995. Modelling Jurassic Milankovitch climate variations. In: House, M.R. \& GALE, A.S. (eds) Orbital Forcing Timescales and Cyclostratigraphy. Geological Society, London, Special Publications, 85, 115-132.

Veizer, J. 1983. Chemical diagenesis of carbonates: Theory and application of trace element technique. In: Arthur, M.A., Anderson, T.F., Kaplan, I.R., Veizer, J. \& LAND, L.S. (eds) Stable isotopes in Sedimentary Geology. Society of Economic Paleontologists and Mineralogists Short Course Notes, 10, 3.1-3.100.

Voigt, S. \& Hilbrecht, H. 1997. Late Cretaceous carbon isotope stratigraphy in Europe: Correlation and relations with sea level and sediment stability. Palaeogeography Palaeoclimatology Palaeoecology, 134, 39-59.

Weissert, H. 1989. C-isotope stratigraphy, a monitor of paleoenvironmental change: a case study from the early Cretaceous. Surveys in Geophysics, 10, $1-61$.

— \& LinI, A. 1991. Ice Age interludes during the time of Cretaceous Greenhouse climate? In: Mueller, D.W., McKenzie J.A. \& Weissert, H. (eds) Controversies in modern Geology. Academic Press, London, 173-191.

Williams, J.R. \& Bralower, T.J. 1995. Nannofossil assemblages, fine fraction stable isotopes, and the paleoceanography of the Valanginian-Barremian (early Cretaceous) North Sea Basin. Paleoceanography, 10, 815-839.

Zachos, J.C., Stott, L.D. \& Lohmann, K.C. 1994. Evolution of early Cenozoic marine temperatures. Paleoceanography, 9, 353-387. 